Економічні науки: збірник наукових прачь Луцького національного технічного університету. - Серія "Регіональна економіка". - Випуск 16 (63). - Редкол.: відп. ред. д.е.н., професор Л.Л. Ковальська - Луцьк : ІВВ Луцького НТУ, 2019. -173 с.

УДК 332.341.1

Ковальська Л.Л., д.е.н., проф.

Таран С.Ф.

Луцький національний технічний університет

\title{
СТАДІЇ ТА ОСОБЛИВОСТІ РОЗВИТКУ ІННОВАЦІЙНОГО ПІДПРИЄМНИЦТВА РЕГІОНУ
}

У статті проведено дослідження стадій та особливостей розвитку інноваційного підприємництва регіону. Виділено такі стадії інноваційного підприємництва регіону: фундаментальні дослідження (зародження ідеї); комерціалізація (створення інновації); прикладна розробка (дослідне виробництво); створення інноваційного продукту (освоєння інновації); споживання. Подано авторський підхід щодо особливостей розвитку інноваційного підприємництва регіону з точки зору обгрунтування суб'єкта, об'єкта, видів, мети, цілей, завдань, результатів та принципів, а також його відмінних ознак від традиційного підприємництва.

Ключові слова: регіон, підприємництво, інноваційне підприємництво, стадії, інновації, комерціалізація, прикладна розробка, фундаментальні дослідження.

\section{Kovalska L., Taran S.}

\section{STAGES AND FEATURES OF INNOVATIVE ENTREPRENEURSHIP DEVELOPMENT IN THE REGION}

The article studies the stages and features of the development of innovative entrepreneurship in the region. The following stages of innovative entrepreneurship in the region are highlighted: fundamental research (idea generation); commercialization (innovation creation); applied development (pilot production); creation of an innovative product (innovation development); consumption. It is proved that at each stage of innovative entrepreneurship there is a need to assess the qualitative and quantitative characteristics of the innovative product as criteria for determining the level of regional development due to the received entrepreneurial income. The author's approach to the peculiarities of the development of innovative entrepreneurship in the region from the point of view of the substantiation of the subject, object, types, purpose, goals, objectives, results and principles, as well as its distinctive features from traditional entrepreneurship is presented. The subjects of innovative entrepreneurship are the subjects of economic activity, the territorial community, territorial administration bodies. The object of innovative entrepreneurship is innovative products (services), the production of which is aimed at the activities of economic entities at each link of the value chain. Such types of 
Економічні науки: збірник наукових праџь Луцького національного технічного університету. - Серія "Регіональна економіка". - Випуск 16 (63). - Редкол.: відп. ред. д.е.н., професор Л.Л. Ковальська - Луиьк: ІВВ Луцького НТУ, 2019. - 173 с.

innovative entrepreneurship as product innovation, technology innovation and social innovation are highlighted. The purpose of innovative entrepreneurship is the transition to an innovative model of economic development in the region. The tasks of innovative entrepreneurship are outlined: creation of communications in the system "science-production"; integration between all stages of innovative entrepreneurship; formation of innovative business education; development of science-intensive industries; effective use of innovative potential; effective use of intellectual resource. The principles of innovative entrepreneurship in the region are given: integration of participants in the innovation process; equality and mutual benefit of subjects of innovative entrepreneurship.

Key words: region, entrepreneurship, innovative entrepreneurship, stages, innovations, commercialization, applied development, fundamental research.

Ковальская Л.Л., Таран С.Ф.

$$
\begin{gathered}
\text { СТАДИИ И ОСОБЕННОСТИ РАЗВИТИЯ } \\
\text { ИННОВАЦИОННОГО ПРЕДПРИНИМАТЕЛЬСТВА } \\
\text { РЕГИОНА }
\end{gathered}
$$

В статье проведено исследование стадий и особенностей развития инновационного предпринимательства региона. Выделены следующие стадии инновационного предпринимательства региона: фундаментальные исследования (зарождение идеи); коммерциализация (создание инновации); прикладная разработка (опытное производство); создание инновационного продукта (освоение инновации); потребление. Подано авторский подход к особенностей развития инновационного предпринимательства региона с точки зрения обоснования субъекта, объекта, видов, целей, задач, результатов и принципов, а также его отличительных признаков от традиционного предпринимательства.

Ключевые слова: регион, предпринимательство, инновационное предпринимательство, стадии, инновации, коммерциализация, прикладная разработка, фундаментальные исследования.

\section{Постановка проблеми у загальному вигляді та іï зв'язок із важливими науковими чи практичними завданнями. В умовах формування інноваційного типу економіки країни, переходу на діджиталізацію усіх суспільних явищ та процесів актуалізуються питання забезпечення розвитку інноваційного підприємництва в усіх регіонах держави. Інноваційне підприємництво покликане впроваджувати нові технології, нові методи та підходи в управлінні економікою регіону, що призводить до зростання інноваційної активності}


Економічні науки: збірник наукових праџь Луцького національного технічного університету. - Серія "Регіональна економіка". - Випуск 16 (63). - Редкол.: відп. ред. д.е.н., професор Л.Л. Ковальська - Луиьк: ІВВ Луиького НТУ, 2019. - 173 с.

регіону, підвищення його конкурентоспроможності та забезпечення переходу на інноваційну модель розвитку. Адже саме ті регіони, які активно розвивають інноваційне підприємництво здатні утримувати міцні конкурентні позиції у ринковому середовищі, успішно себе позиціонувати у міжнародному економічному просторі. У зв'язку із цим, актуалізуються питання дослідження особливостей розвитку інноваційного підприємництва регіону з позиції забезпечення тісного зв'язку в системі «фундаментальні дослідження прикладні дослідження - комерціалізація - виробництво».

Аналіз останніх досліджень і публікацій, в яких започатковано розв'язання даної проблеми. В теоретичному аспекті дослідження особливостей розвитку інноваційного підприємництва регіону знайшли своє відображення у працях Козоріз М. [1], Кривов'язюка I. [4, 5], Ляшенко В. [2], Рудь Н. [9], Федорова Ю. [6], Федулової Л. [11], Хопкінсона Л. [3] та ін. Проте, i досі дискусійними залишаються питання виявлення особливостей розвитку інноваційного підприємництва на регіональному рівні.

Цілі статті. Тому, проведемо теоретичні дослідження стадій та особливостей розвитку інноваційного підприємництва регіону.

Виклад основного матеріалу дослідження 3 повним обгрунтуванням отриманих наукових результатів. Досить важливим питанням в умовах забезпечення інноваційної активності регіонів держави є формування нових технологічних укладів економіки, забезпечення тісного зв'язку в системі «фундаментальні дослідження - прикладні дослідження комерціалізація - виробництво», підвищення ефективності комерціалізації наукових розробок. Розглядаючи стадії інноваційного підприємництва (рис. 1), слід зауважити, що висхідною точкою до отримання підприємницького доходу $є$ зародження ідеї, проте лише шляхом комерціалізації вона трансформується в інновацію. 
Економічні науки: збірник наукових прачь Луцького національного технічного університету. - Серія "Регіональна економіка". - Випуск 16 (63). - Редкол.: відп. ред. д.е.н., професор Л.Л. Ковальська - Луиьк: ІВВ Луиького НТУ, 2019. - 173 с.

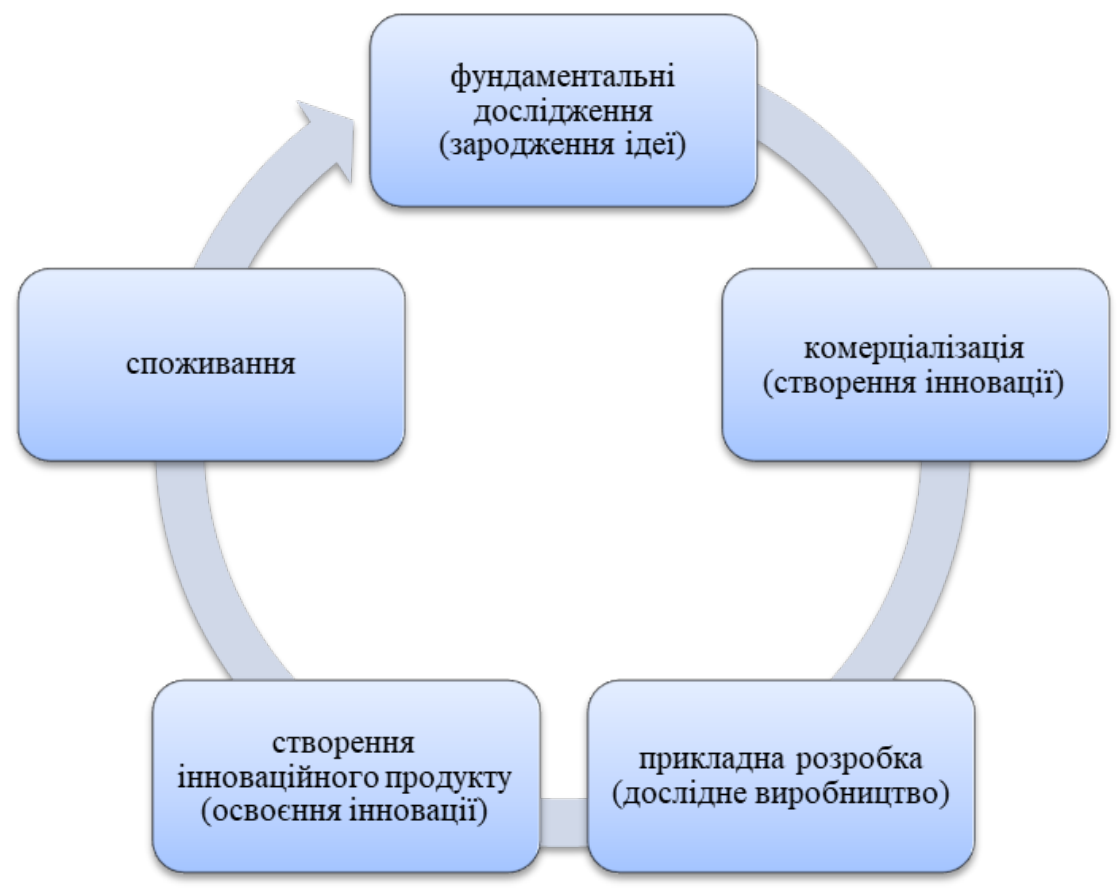

Рис.1. Стадії інноваційного підприємництва

В свою чергу, прикладні розробки спрямовані на розробку проектів створення інноваційних продуктів, визначення оптимальних параметрів їх споживання та сфер їх застосування у регіональній чи національній економіці [1, с. 11-12], в результаті чого створюється дослідне виробництво. На наступній стадії відбувається матеріалізація нових ідей, в результаті чого освоюються інновації та здійснюється виробництво інноваційних продуктів. Такі інноваційні продукти переходять у стадію споживання та задовольняють потреби населення регіону у високотехнологічних продуктах та послугах.

Як влучно зауважено у [2; 3] нові ідеї, що стають результатом креативного мислення, як правило, не можуть бути 
Економічні науки: збірник наукових прачь Луцького національного технічного університету. - Серія "Регіональна економіка". - Випуск 16 (63). - Редкол.: відп. ред. д.е.н., професор Л.Л. Ковальська - Луцьк: ІВВ Луиького НТУ, 2019. - 173 с.

негайно запущені у виробництво. Між науковими ідеями i технологіями існує великий розрив, для подолання якого потрібен досить специфічний набір знань і компетенцій.

Чим складніше влаштована інновація з погляду наявного науково-технічного знання, тим більша асиметрія в розумінні іiі можливостей між автором інновації й суб'єктом економічної діяльності, що здобуває права на неї (так званий інноваційний пробіл, або «долина смерті») [3].

Слід зауважити, що на кожній стадії інноваційного підприємництва виникає потреба у оцінці якісних та кількісних характеристик інноваційного продукту як критеріїв визначення рівня регіонального розвитку за рахунок отриманого підприємницького доходу. 3 іншої сторони, ці критерії виступають мірилом технологічного укладу економіки регіону. Можливості інноваційного розвитку значною мірою залежать від домінування у регіоні тих чи інших технологічних укладів, розвиток яких впливає на формування конкурентної переваги у виробництві різних видів продукції [4, с.100]. Технологічний уклад відображає досягнення регіону (країни) у інноваційнотехнологічному розвитку, котре забезпечує їх конкурентну перевагу над іншими регіонами (країнами) у виробництві певних видів продукції, забезпечуючи, при цьому, формування високоефективної технологічної структури економіки $[5$, с. 80]. На жаль, сьогодні в Україна розвинені III та IV технологічні уклади, їх сумарна питома вага складає 95\%. На V технологічний уклад приходиться $5 \%$, а шостий взагалі відсутній [6]. Як бачимо, сучасні тенденції розвитку інноваційного підприємництва у регіонах держави стримують розвиток технологічного укладу, в результаті чого інноваційна продукція не $\epsilon$ конкурентоспроможною, а відтак постає проблема формування нової моделі інноваційного розвитку економіки регіону із орієнтацією на вищі технологічні уклади.

$$
\text { Досліджуючи третю складову інноваційного }
$$
підприємництва, якими є наука та виробництво, то важливим постає завдання побудови ефективної їх взаємодії за допомогою різних організаційних форм інтеграції. Такими формами 
Економічні науки: збірник наукових праць Луцького національного технічного університету. - Серія "Регіональна економіка". - Випуск 16 (63). - Редкол.: відп. ред. д.е.н., професор Л.Л. Ковальська - Луиьк: ІВВ Луцького НТУ, 2019. - 173 с.

інтеграції можуть бути технопарки, технополіси, бізнесінкубатори, регіональні інноваційні центри тощо. Інтеграція науки та виробництва дозволить утворити організаційну основу ведення інноваційного підприємництва, відіграти важливу роль у перенесенні високих технологій зі сфери фундаментальних розробок у виробництво і сприяти комерціалізації науки у реальну практику виробництва інноваційного продукту (послуги) [7, 8]. Як зазначено у [9], нова регіональна інноваційна модель характеризується нелінійними інтерактивними процесами, які вимагають інтенсивних комунікацій i взаємодії між ключовими складовими регіональної інноваційної системи, центрами трансферу технологій, технопарками, науково-дослідними інститутами, вищими навчальними закладами, малими інноваційними підприємствами, промисловими підприємствами, адміністрацією регіону та ін. Проте, недосконалість комунікаційних зв'язків в системі наука-виробництво породжує появу проблем у розвитку інноваційного підприємництва регіону: зниження кількості інноваційно активних підприємств, недостатній обсяг випуску інноваційної продукції, відтік інтелектуального ресурсу за межі держави та ії регіонів, низький рівень інноваційної бізнес-освіти, низький рівень зацікавленості молодого покоління у реалізації інноваційних ідей тощо. Тому, слід створити стійкі економічні зв'язки в системі «наука виробництво», де будуть переплітатися бізнес-інтереси суб'єктів інноваційного підприємництва, сформується ланцюг створення вартості інноваційного продукту та ефективно використовуватиметься наявний інноваційний потенціал.

Водночас, важливим постає питання визначення особливостей розвитку інноваційного підприємництва регіону 3 точки зору обгрунтування суб'єкта, об'єкта, видів, мети, цілей, завдань, результатів та принципів, а також його відмінних ознак від традиційного підприємництва. Особливості розвитку інноваційного підприємництва регіону наведено у таблиці 1. 
Економічні науки: збірник наукових праць Луцького національного технічного університету. - Серія "Регіональна економіка". - Випуск 16 (63). - Редкол.: відп. ред. д.е.н., професор Л.Л. Ковальська - Луцьк: ІВВ Луиького НТУ, 2019. -173 с.

Таблиця 1

Особливості розвитку інноваційного підприємництва регіону

\begin{tabular}{|c|c|c|}
\hline Складові & $\begin{array}{c}\text { Особливості розвитку } \\
\text { інноваційного } \\
\text { підприємництва } \\
\end{array}$ & $\begin{array}{c}\text { Особливості розвитку } \\
\text { традиційного підприємництва }\end{array}$ \\
\hline 1 & 2 & 3 \\
\hline Суб'єкт & $\begin{array}{lr}\text { Суб’єкт } & \text { господарської } \\
\text { діяльності, } & \text { територіальна } \\
\text { громада, } & \text { органи } \\
\text { територіального управління }\end{array}$ & \begin{tabular}{lrr} 
Фізичні, & юридичні & особи, \\
громадяни України, іноземці та \\
особи без & громадянства, які \\
здійснюють & \multicolumn{2}{c}{ господарську } \\
діяльність & та & зареєстровані \\
відповідно & до & закону як \\
підприємці & &
\end{tabular} \\
\hline Об’єкт & $\begin{array}{l}\begin{array}{l}\text { Інноваційний } \\
\text { (послуга, робота) }\end{array} \\
\end{array}$ & Продукція, робота, послуга \\
\hline Види & $\begin{array}{l}\text { Інновація продукції; } \\
\text { інновація технології; } \\
\text { соціальні інновації }\end{array}$ & $\begin{array}{l}\text { Соціальне, } \\
\text { комерційне, виробниче та ін. }\end{array}$ \\
\hline Мета & $\begin{array}{l}\text { Перехід на інноваційну } \\
\text { модель розвитку економіки } \\
\text { регіону }\end{array}$ & $\begin{array}{l}\text { Досягнення економічних } \\
\text { соціальних результатів }\end{array}$ \\
\hline Цілі & 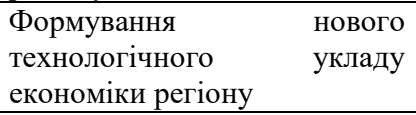 & $\begin{array}{l}\text { Формування } \\
\text { середовища }\end{array}$ \\
\hline Завдання & 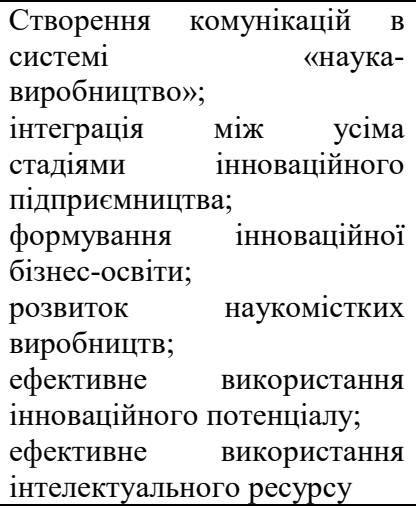 & 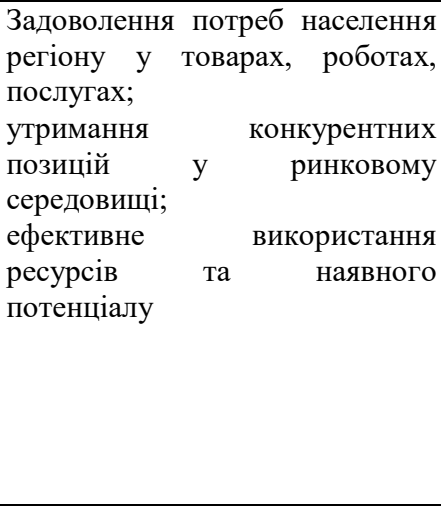 \\
\hline Результат & $\begin{array}{l}\text { Отримання } \\
\text { підприємницького доходу }\end{array}$ & Одержання прибутку \\
\hline Ресурси & Інтелектуальний ресурс & $\begin{array}{l}\text { Виробничі ресурси (природні, } \\
\text { матеріально-технічні, } \\
\text { фінансові, людські) }\end{array}$ \\
\hline
\end{tabular}


Економічні науки: збірник наукових прачь Луцького національного технічного університету. - Серія "Регіональна економіка". - Випуск 16 (63). - Редкол.: відп. ред. д.е.н., професор Л.Л. Ковальська - Луиьк: ІВВ Луиького НТУ, 2019. - 173 с.

Продовження таблиці 1

\begin{tabular}{|c|c|c|}
\hline 1 & 2 & 3 \\
\hline Принципи & $\begin{array}{lr}\text { Iнтеграція } & \text { учасників } \\
\text { iнноваційного процесу; } \\
\text { рівноправність } \\
\text { взаємовигідність } \\
\begin{array}{l}\text { iнноваційного } \\
\text { підприємництва }\end{array} \\
\text { суб'єктів } \\
\end{array}$ & 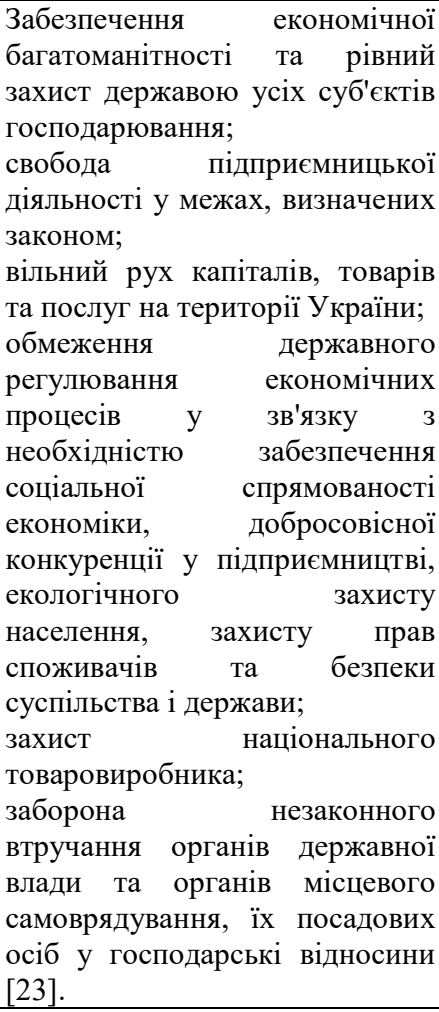 \\
\hline
\end{tabular}

Як бачимо, інноваційне підприємництво має свої специфічні особливості порівняно із традиційним підприємництвом. Розглянемо ці особливості. Суб'єктами інноваційного підприємництва виступають суб'єкти здійснення господарської діяльності, територіальна громада, органи територіального управління. Об'єктом інноваційного підприємництва виступає інноваційна продукція (послуга), на випуск якої спрямована діяльність суб'єктів господарювання на кожній ланці створення ланцюга вартості. 
Економічні науки: збірник наукових праць Луцького національного технічного університету. - Серія "Регіональна економіка". - Випуск 16 (63). - Редкол.: відп. ред. д.е.н., професор Л.Л. Ковальська - Луцьк: ІВВ Луцького НТУ, 2019. - 173 с.

В економічній літературі виділяються три основні види інноваційного підприємництва [10]:

1. Інновація продукції - являє собою процес оновлення збутового потенціалу суб'єкта господарювання, що забезпечує його стійкий розвиток, збільшення обсягу одержуваного прибутку, розширення частки на ринку, збереження клієнтури, зміцнення незалежного положення, підвищення престижу, створення нових робочих місць і т. д.

2. Інновація технології - це процес оновлення виробничого потенціалу, спрямований на підвищення продуктивності праці та економію енергії, сировини та інших ресурсів, що в свою чергу дає можливість збільшити обсяг прибутку суб'єкта підприємницької діяльності, провести заходи щодо захисту навколишнього середовища, ефективно використовувати внутрішньофірмові інформаційні системи.

3. Соціальні інновації - представляє собою загальний процес планомірного поліпшення гуманітарної сфери суб'єкта господарювання. Застосування інновацій такого роду розширює можливості на ринку робочої сили, мобілізує персонал підприємства на досягнення поставлених цілей, зміцнює довіру до соціальних зобов'язаннях підприємства перед співробітниками і суспільством в цілому [10].

Метою здійснення інноваційного підприємництва $\epsilon$ перехід на інноваційну модель розвитку економіки регіону. Саме такий перехід дозволить досягти основну ціль інноваційного підприємництва - сформувати новий технологічний уклад економіки регіону вищого порядку. Для досягнення цієї цілі слід реалізувати такі завдання інноваційного підприємництва як:

- створення комунікацій в системі «наукавиробництво»;

- інтеграція між усіма стадіями інноваційного підприємництва;

- формування інноваційної бізнес-освіти;

- розвиток наукомістких виробництв;

- ефективне використання інноваційного потенціалу; 
Економічні науки: збірник наукових праць Луцького національного технічного університету. - Серія "Регіональна економіка". - Випуск 16 (63). - Редкол.: відп. ред. д.е.н., професор Л.Л. Ковальська - Луиьк: ІВВ Луиького НТУ, 2019. - 173 с.

- ефективне використання інтелектуального ресурсу.

Інноваційне підприємництво представляє собою специфічний вид діяльності, «фундаментом» якого $\epsilon$ інтелектуальний ресурс. Саме інтелектуальний ресурс є тим каталізатором ідей, які здатні трансформуватись в конкурентоспроможний інноваційний продукт.

На відміну від традиційного підприємництва, принципами інноваційного підприємництва $\epsilon$ : інтеграція учасників інноваційного процесу; рівноправність та взаємовигідність суб'єктів інноваційного підприємництва.

Висновки. Успішна реалізація цілей та завдань інноваційного підприємництва дозволить забезпечити досягнення основного результату - це отримання підприємницького доходу, який відображатиме рівень розвитку регіональної економіки та позитивні впливові ефекти на національну економіку та рівень ¥і1 глобальної конкурентоспроможності в цілому.

1. Управління інноваційними процесами в регіонах: Монографія. Інститут регіональних досліджень НАН України; Львівський банківський інститут НБУ; За наук. ред. д-ра екон. наук, проф. М.А.Козоріз, д-ра екон. наук, проф. Т.С. Смовженко. Львів: ЛБІ НБУ, 2006. 263 с.

2. Ляшенко B.I., Тульку Я.І. Мале інноваційне підприємництво як об’єкт державної інноваційної політики // Економічні інновації. Вип.59. 2015. C. 219-227.

3. Хопкинсон Л. Поддержка инновации на уровне регионов и муниципалитетов. Режим http://eep.org.ua/files/MANUAL\%204\%20Feb\%202013.pdf.

4. Кривовязюк I.В. Інноваційна економіка: навчальний посібник. Київ: Кондор-Видавництво, 2016. 384 с.

5. Kryvovyazyuk I.V., Volynchuk Y.V., Pushkarchuk I.M. The dominance of technological regimes in the countries of innovative economy. Economics, Management, Law: Problems and Prospects: Collection of scientific articles. Agenda Publishing House, Coventry, United Kingdom. 2015. P. 79-82.

6. Федорова Ю.В. Перспективи інноваційного розвитку України: технологічні уклади. Вісник Хмельницького національного університету. 2016. №1. C. 123-126.

7. Ковальська Л.Л., Герасимчук 3.В. Виробничий потенціал регіону: методика оцінки та механізми нарощення: [Монографія]. Луцьк.: ЛДТУ, 2003. $242 \mathrm{c.}$ 
Економічні науки: збірник наукових праць Луцького національного технічного університету. - Серія "Регіональна економіка". - Випуск 16 (63). - Редкол.: відп. ред. д.е.н., професор Л.Л. Ковальська - Луиьк: ІВВ Луцького НТУ, 2019. - 173 с.

8. Ковальська Л.Л. Оцінка конкурентоспроможності регіону та механізми ії підвищення: [Монографія] Ковальська Л.Л. Луцьк.: ЛДТУ, 2007. $385 \mathrm{c}$.

9. Рудь Н.Т. Роль інноваційних стратегій у підвищенні інноваційного потенціалу регіону. Економіка. Управління. Інновації. 2010. № 2. Режим доступу: http://nbuv.gov.ua/UJRN/eui 2010237.

10. Економіка підприємства: навчальний посібник. / уклад. Мішенін Е.О., Балацький Є.О.,Дутченко О.М., Шамота Г.М., Гузь М.М., Дутченко О.О. Харків : «Диса Плюс», 2015, 336 с.

11. Федулова Л.І. Дослідження методик оцінювання інноваційного потенціалу промислових підприємств // Держава та регіони. 2008. № 4. c. $234-240$. 